\title{
Arbor
}

\section{Los orígenes de la aventura}

\author{
Joaquín $M^{a}$ Córdoba
}

Arbor CLXXX, 711-712 (Marzo-Abril 2005), 445-449 pp.

Aunque el redescubrimiento de Oriente a través de la literatura de viajes más citada comienza en el siglo XII, los orígenes de la aventura se remontan muy atrás, porque para los griegos primero y los romano-bizantinos después, un cierto Oriente era ya su "otro" más cercano. Pero acaso muchos ignoren que en los extremos del tiempo que evocamos, los relatos más tempranos e interesantes son tres que escritos respectivamente en latín, hebreo y árabe, se deben a otros tantos y singulares viajeros nacidos en la Península Ibérica.

En época clásica, Heródoto de Halicarnaso, nacido súbdito del imperio aqueménida, aprovechó la paz de Calias (449 a.C.) para visitar Oriente, viajando por Anatolia y Mesopotamia, informándose de las costumbres persas y babilonias, describiendo el imperio de Darío y su geografía, sus pueblos y sus maravillas ${ }^{1}$. Al igual que él, muchos otros griegos viajaron por Oriente o vivieron junto al Gran Rey, como Cetesias de Cnido, que a fines del siglo $\mathrm{V}$ ejerció como médico de Artajerjes II y la reina Parisátides, y aprovechó su estancia en la corte para escribir de su imperio y de mundos más remotos aún ${ }^{2}$. La conquista de Alejandro parecía integrar Oriente y Occidente, y con el Periplo de Nearco los griegos supieron incluso de las lejanas costas del Índico y el Golfo Pérsico ${ }^{3}$. Pero el imperio del macedonio fue efímero, y a poco de su muerte el antiguo Oriente aqueménida quedó partido en dos mundos, el de los reinos helenísticos y los imperios romano y bizantino por un lado, y el de los imperios parto (238 a.C.- 224 d.C.) y sasánida (224642 d.C.) por otro.

Sin embargo, la división temprana entre el Oriente romano-bizantino y el parto-sasánida no fue tan radical como cabría pensar, pese a guerras y batallas sin cuento. Por ejemplo, tras la paz firmada entre Augusto y Fraates IV el 20 a.C., un escritor nacido en una ciudad enclavada en el 
curso inferior del Tigris, llamado por ello Isidoro de Cárax, escribió para Augusto las Estaciones Partas, en las que describe un itinerario que llevaba desde el Éufrates hasta Afganistán, obra que quizás resume otra más ambiciosa y perdida, una especie de «Viaje a través de Partia» ${ }^{4}$. Pero gracias a sus relatos, los romanos supieron de grandes ciudades del Asia Central como la de Asaac, donde Arsaces había sido coronado rey, o la gran ciudad de Nisa, en la que se custodiaban las tumbas reales de los partos $^{5}$

Casi un siglo después, otro romano oriental llamado Flavio Arriano, natural de Nicomedia de Bitinia, escribió además de su célebre Anábasis de Alejandro Magno, una Historia de los Partos en 17 libros, que aún perdida, por lo menos evidencia el vivo interés existente por el imperio iranio. Y luego, las experiencias bélicas de Amiano Marcelino en la segunda mitad del siglo IV, recrearían dramáticamente la guerra romano-sasánida por al Yazira, o la pavorosa magnitud del ejército del Rey de Reyes ${ }^{6}$. Pues bien, por aquellos años hacía tiempo que estaba en auge la peregrinación cristiana a Oriente, y entre los relatos conocidos de tan piadosos viajes, desde el atribuido al Peregrino de Burdeos ( 333 d.C.) hasta el Itinerario de Placentino (ca. 570 d.C.), resalta el de una mujer excepcional llamada Egeria, miembro de la familia imperial y originaria de Hispania, cuyo periplo (ca. 381-384 d.C.) y su narración posterior constituye el primero de los libros españoles de viaje a Oriente.

No mucho después sin embargo, la ruptura entre Oriente y Occidente se haría dramática, el olvido del pasado total y la confusión en aquel presente absoluta. A poco de alcanzarse la paz (628 d.C.) entre Kavad II y Heraclio, tras casi veinte años de feroz guerra para ambos imperios, a comienzos del año 636 los árabes musulmanes aniquilaban lo mejor del ejército sasánida en Q⿱ādisīyah ${ }^{7}$, y en agosto del mismo año aplastaban a los bizantinos en Yarmū $k^{8}$. Pronto, toda Siria, Palestina, Mesopotamia e Irán obedecerían al Califato. Y a partir de entonces, guerras y religiones fueron separando más y más a Oriente de Occidente, pues como escribió H. Pirenne, «los árabes (musulmanes) estaban exaltados por una fe nueva", que al impregnar profundamente su cultura y sus costumbres les hacía inasimilables, tanto que mientras los germanos se habían romanizado al entrar en el imperio, los árabes musulmanes por el contrario arabizaron a los romanos orientales ${ }^{9}$. La ruptura entre ambos mundos podríamos simbolizarla en la agitada vida de Juan Mosco, monje en el monasterio palestino de San Teodosio, fugitivo de los sasánidas, cuya voluntad de ser enterrado en el Sinaí se 
vió impedida por la invasión árabe ${ }^{10}$. O con los cantos de frontera y la imagen del héroe Basilio Digenís Akritas, campeón de la defensa del imperio ante los musulmanes ${ }^{11}$.

Al islamizarse, los mundos del Oriente romano-bizantino y el Irán sasánida cambiaron radicalmente sus valores, su escritura e incluso su lengua en Mesopotamia y la parte occidental. Durante mucho tiempo, la unidad económica y cultural del Mediterráneo quedó rota. En el 711, el Islám se extendía por casi toda la Península Ibérica y en el 720, piratas sarracenos asediaban ya las costas y el puerto de Marsella, donde cuatro años antes se recibían aún mercancías de Oriente. En esta situación, a lo largo de los siglos VIII y IX y aún después, algunos venecianos, y sobre todo los comerciantes judíos, se convertirían en los más hábiles agentes de contacto entre ambos mundos -como escribe Ibn Hurdadbeh en su Libro de las rutas ${ }^{12}$, actuando incluso como embajadores de 'Abd al-Rahmān III (929-961) o al Hakem II (961-976), cuando enviados por el ministro Hasdai ibn Safrut, marcharon por Rusia y el Volga a la búsqueda del reino de los jázaros ${ }^{13}$. Otros, como Ibrāhīm ben Ya'qūb al Isra'ili, recorrerían Europa occidental por la misma época ${ }^{14}$. Pero ninguno de ellos dejó recuerdo escrito de sus aventuras, a diferencia de los muchos viajeros musulmanes, que por mar y tierra pondrían en contacto los extremos más lejanos de su mundo, desde China hasta la Península Ibérica. Así, la anónima Relación de la China y la India, escrita en el $851^{15}$, los viajes y exploraciones de Ibn Fadlān por el Jorezm y los territorios de turcos, pechenegos y basquires a comienzos del $\mathrm{X}^{16}$, o los relatos del palestino al Muqaddasī a fines del mismo siglo $\mathrm{X}^{17}$. Todos ellos fueron desarrollando el género literario del risāla, origen a su vez de otro nuevo, el rihla o diario de viaje, que como el Séfer-Masa'ot hebreo iban a ser creados por viajeros salidos de nuestra península.

Con la conquista de Jerusalén (1099) y la formación del Reino Latino de los francos, la navegación europea por el Mediterráneo se hizo mucho más intensa, favoreciéndose así los viajes y las peregrinaciones de todo tipo, incluso las de los musulmanes del Andalus y los comerciantes de cualquier nación. Y en los años que precedieron a la reconquista de Jerusalén por Saladino $(1187)^{18}$, un rabino navarro llamado Benjamín de Tudela llegaba a Palestina (1166), en el curso de un viaje que luego dejaría por escrito. Pocos años después (1183), otro viajero de la Península llamado Ibn Ŷubair peregrinaría a La Meca, recorríendo luego Iraq, Siria y el reino de los francos, dejándonos más tarde con sus recuerdos escritos, el primer diario de viaje de la literatura árabe. 
Y con estos tres grandes viajeros, la noble dama hispano-romana Egeria, el rabino Benjamín de Tudela y el musulmán Ibn Ŷubair comienza la verdadera historia del redescubrimiento de Oriente hecho por los viajeros españoles.

\section{Notas}

1 HeRóDOto: sobre las costumbres de los persas en I, 131-140: de las babilonias en I, 192-200. La descripción del imperio de Darío y su geografía puede seguirse en III, 89-117. Pueden consultarse la edición de Carlos Schrader: Historia, Libros I-II, Editorial Gredos, S. A., Madrid (1992), Historia, Libros III-IV, Editorial Gredos, S. A., (1986), Madrid.

2 Gómez Espelosín, Fco. J. (2000): El descubrimiento del mundo. Geógrafos y viajeros en la antigua Grecia. Ediciones Akal, S. A., Madrid, pp. 253-258.

3 A las contingencias del Periplo de Nearco y a la descripción de las gentes y paisajes que conoció aquel dedica Arriano su Libro VIII, 181-43.14. Una buena edición es la de Antonio Guzmán Guerra, ArRIANo, Anábasis de Alejandro Magno. Libros I-III, Editorial Gredos, S. A., Madrid 1982. Libros IV-VIII (India), Editorial Gredos, S. A., Madrid 1982.

${ }^{4}$ Schoff, W. H. (1914): Parthian Stations by Isidore of Charax. An account of the overland trade routes between the Levant and India in the first century B. C. The Commercial Museum, Philadelphia, p. 17.

5 SCHOFF, W. F. (1914): op. cit. p. 9.

6 Amiano Marcelino: De la guerra y los ejércitos enfrentados y sus jefes, desde las primeras batallas vividas por Amiano hasta la campaña de Juliano, se puede leer en los libros 18 (4.1-10.4), 19 (1.1-10.4), 20 (6.1-7.18), 23(1.1-5.25), 24 (1.1-8.7) у 25 (1.1-9.13). Es muy curiosa la descripción del Imperio Sasánida, hecha en el libro 23 (6.1-6.88). Una buena versión española en la edición de $\mathrm{M}^{\mathrm{a}}$ Luisa Trujillo, Historia, Ediciones Akal, S. A., Madrid 2002.

7 SchippmanN, K. (1990): Grundzüge der Geschichte des sasanidischen Reiches. Wissenschaftliche Buchgesellschaft, Darmstadt, p. 75.

8 Nicole, D. (1995): Yarmuk 636 a. C. Los musulmanes conquistan Siria. Ediciones del Prado, Madrid.

9 Pirenne, H. (1978): Mahoma y Carlomagno. Alianza Editorial, Madrid, pp. 124-125

10 Simon Palmer, J. (ed.) (1999): Historias bizantinas de locura y santidad. Juan Mosco, El Prado. Leoncio de Neápolis, Vida de Simeón el Loco. Ediciones Siruela, Madrid, p. 11.

11 Valero Garrido, J. (ed.) (1981): Basilio Digenís Akritas (edición bilingüe) Bosch, Casa Editorial S. A., Barcelona. Una versión más reciente, sólo en español en Ó. MARTíNEZ GARĆíA, (ed.) (2002): Poesía heroica bizantina: Canción de Armuris, Digenís Akritas, Poema de Belisario. Editorial Gredos, S. A., Madrid.

12 PiRenNe, H. (1978): op.cit. p. 208.

13 GonzÁlez Llubera, I. (ed.) (1918): Viajes de Benjamín de Tudela, Madrid 1918, p. 22.

14 ANTelo Iglesias, A. (1991): Judíos españoles de la Edad de Oro (siglos XI-XII). Universidad Nacional de Educación a Distancia, Madrid, p. 304.

15 Miquel, A. (1967): La géographie humaine du monde musulman jusqu'au milieu du 11e siècle. Livre I. Mouton \& Co., Paris-La Haye, p. 116.

16 MiQuel, A. (1967): op. cit. p. 132. 


\section{Los orígenes de la aventura}

17 ARIOLI, A. (1992): Islario maravilloso. Periplo árabe medieval. Julio Ollero Editor, S. A., Madrid, p. 219.

18 Runciman, S. (1973) : Historia de las Cruzadas, Alianza Editorial, Madrid. Sobre la conquista cristiana véase volumen I, pp. 265-273. La reconquista de Saladino en volumen II, pp. 417-422. 